\title{
Association of vitamin D receptor gene polymorphisms with pancreatic cancer: A pilot study in a North China Population
}

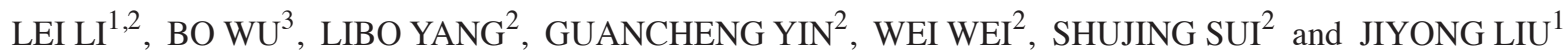 \\ ${ }^{1}$ Department of Gastroenterology, Shandong Provincial Hospital, Shandong University, Jinan 250021; \\ ${ }^{2}$ Department of Internal Medicine, Taian City Central Hospital; ${ }^{3}$ Department of General Surgery, \\ Taian Eighty-Eight Hospital, Taian 271000, P.R. China
}

Received December 5, 2012; Accepted February 20, 2013

DOI: $10.3892 / \mathrm{ol} .2013 .1215$

\begin{abstract}
Polymorphisms of the vitamin D receptor (VDR) gene may be a risk factor for pancreatic cancer (PC). We investigated the association of two single-nucleotide polymorphisms (SNPs) of the VDR gene with PC in age- and gender-matched patients and controls. PC $(n=91)$ and healthy control $(n=80)$ samples were genotyped for the FokI (rs2228570) and BsmI (rs1544410) polymorphisms using the PCR and restriction fragment length polymorphism (PCR-RFLP) method. Chi-square analysis was used to test for the overall association of VDR genotype with disease. There was a significant difference in the frequency of genotype FF between the PC patients and controls ( $\mathrm{P}^{\text {trend }}=0.009$ ); however, the difference in frequency of genotype BB between the two groups was not significant $\left(\mathrm{P}^{\text {trend }}=0.082\right)$. The difference between $\mathrm{FF}$ and Ff/ff frequency was significant $(\mathrm{P}=0.002)$. The two high-risk genotypes were ffbb and Ffbb, with an 11.66- and 6.42-fold increased risk of PC, respectively. VDR gene polymorphisms were important for the development of PC in this study population; however, further exploration of these findings and their implications are required.
\end{abstract}

\section{Introduction}

Pancreatic cancer (PC) is one of the most lethal human malignant tumors and accounts for $3 \%$ of all reported cases of cancer (1). It is estimated to have been responsible for $>250,000$ mortalities and was the fifth leading cause of cancer-associated deaths worldwide in 2007 (2). The prognosis for $\mathrm{PC}$ is extremely poor, with a 5-year survival rate of $<5 \%$, even with surgical and chemotherapeutic intervention (3). It has been shown that $1 \alpha, 25(\mathrm{OH})_{2} \mathrm{D}_{3}$ acts as a type of hormone

Correspondence to: Professor Jiyong Liu, Department of Gastroenterology, Shandong Provincial Hospital, Shandong University, 324 Jing 5 Road, Jinan 250021, P.R. China

E-mail: lilktaian@126.com

Key words: vitamin D receptor gene, FokI, BsmI, polymorphism, pancreatic cancer, North China and significantly inhibits the proliferative activity of numerous types of cancer cells, including PC cells, in vitro and regulates growth and differentiation in various cell types $(4,5)$. It acts by binding to a corresponding intranuclear vitamin $\mathrm{D}$ receptor (VDR), which is present in a number of target tissues $(6,7)$.

Numerous studies have demonstrated that polymorphisms of the VDR gene have important implications in VD signaling and are associated with various malignancies, including cancer of the colon, breast, kidneys and prostate (8-12). However, little is known about the role of the VD endocrine system in the carcinogenesis of PC.

Therefore, the aim of this study was to screen for genetic variations of two single-nucleotide polymorphisms (SNPs), FokI (rs2228570) and BsmI (rs1544410), of the VDR gene in a well-defined population of individuals with PC and compare their incidence with that of a healthy control population, in order to determine the contribution of VDR polymorphisms to $\mathrm{PC}$ in North China.

\section{Materials and methods}

Study participants. This study was part of an ongoing hospitalbased case-controlled study, conducted at three hospitals (Shandong Provincial Hospital, Taian Central Hospital and Taian Eighty-eight Hospital, Shandong, China). The purpose of this study was to define risk factors which contribute to the development of PC. PC patients $(n=91)$ eligible for the current study were enrolled between January 12010 and June 302012. Diagnosis of the samples was confirmed by certified histopathologists (only pancreatic adenocarcinoma was included) in the three hospitals mentioned above. Formalin-fixed paraffin-embedded tissues from PC patients $(n=91)$ were used. The control group consisted of 80 healthy volunteers, selected by age- and gender-matching to the PC patients. The volunteers had no history of any type of cancer at the time of recruitment. Written informed consent was obtained from patient's and volunteer's families. This study was approved by the Ethical Committees of the three hospitals.

$D N A$ isolation in $P C$. The required thin $(10 \times 10 \mu \mathrm{m})$ tissue sections were dried onto slides at $37^{\circ} \mathrm{C}$ overnight. After soaking the tissue sections in xylene, deparaffinization was carried out with ethanol series for 3-5 min each (100\% ethanol 
for dehydration and 80,60 and 40\% ethanol). To differentiate healthy tissue from tumor tissue, the slides were stained with hematoxylin. Tumor tissues were isolated by microdissection and the DNA was extracted using a DNA Isolation kit (Sangon Biotech, Inc., Shanghai, China), according to the manufacturer's instructions.

DNA isolation from peripheral venous blood of control population. Peripheral venous blood was obtained from each healthy volunteer and promptly centrifuged $(1,500 \mathrm{x} \mathrm{g}$ for $10 \mathrm{~min})$. Genomic DNA was extracted from $200 \mu 1$ EDTA blood with a DNA Isolation kit from Roche Diagnostics (Sangon Biotech, Inc.), according to the manufacturer's instructions. To obtain higher DNA concentrations, a number of blood samples intially underwent lymphocyte separation, performed according to the manufacturer's instructions (Sangon Biotech, Inc.). Briefly, $3 \mathrm{ml}$ diluted blood samples were carefully centrifuged at $1,200 \mathrm{x}$ g for $20 \mathrm{~min}$ at $25^{\circ} \mathrm{C}$ and lymphocytes from the interphase were washed twice in phosphate-buffered saline (PBS). DNA was then isolated as described above.

Genotyping of FokI. According to the method described by Arjumand et al (11) and Harries et al (13), the polymorphisms of VDR [FokI (rs10735810) and BsmI (rs1544410)] were assayed using the PCR and restriction fragment length polymorphism (PCR-RFLP) method. Genomic DNA ( $2 \mu \mathrm{l})$ was used, in addition to $200 \mathrm{ng}$ of forward and reverse primers, 1 X Taq polymerase buffer $\left(1.5 \mathrm{M} \mathrm{MgCl}_{2}\right)$, dNTPs $(0.3 \mathrm{mM})$ and 1 unit of Taq DNA polymerase (Sangon Biotech, Inc.). The primers of the VDR gene used were forward (5'-AGCTGGCCCTGGCACTGACTCTGCTCT-3') and reverse (5'-ATGGAAACACCTTGCTTCTTCTCCCT-C-3'). PCR amplification was carried out with the following cycling parameters: denaturation at $94^{\circ} \mathrm{C}$ for $5 \mathrm{~min}, 35$ cycles at $94^{\circ} \mathrm{C}$ for $30 \mathrm{sec}, 61^{\circ} \mathrm{C}$ for $30 \mathrm{sec}$ and $72^{\circ} \mathrm{C}$ for $1 \mathrm{~min}$ and one final cycle of extension at $72^{\circ} \mathrm{C}$ for $7 \mathrm{~min}$. The $\mathrm{C} / \mathrm{T}$ polymorphism in the first of the two-start codon (ATG) at the translation initiation site of the VDR gene was detected by RFLP, using the restriction endonuclease FokI (Sangon Biotech, Inc.). The PCR product of the 265-bp band was digested with 5 units of FokI restriction enzyme and incubated at $37^{\circ} \mathrm{C}$ for $4 \mathrm{~h}$. The digested reaction mixture $(10 \mu \mathrm{l})$ was then loaded using $2 \%$ agarose gel containing ethidium bromide and visualized under short-wave UV light. The sizes were determined using a 100-bp ladder (Sangon Biotech, Inc.). Digestion of the amplified 265-bp PCR product yielded two fragments: 169 and 96 bp. Depending on the digestion pattern, individuals were scored as FF when homozygous for the presence of the FokI site, ff when homozygous for absence of the FokI site or Ff in the case of heterozygosity.

Genotyping of BsmI. The PCR amplification was carried out with the following cycling parameters: denaturation at $94^{\circ} \mathrm{C}$ for $5 \mathrm{~min}$ and 35 cycles at an annealing temperature of $66^{\circ} \mathrm{C}$ with the following primers: forward (5'-CAACCAAGACTACAAGTACCGCGTCAGTGA-3') and reverse (5'-AACCAGCGGGAAGAGGTCAAGGG-3'). The 800-bp PCR product was then diluted and digested with enzyme $B s m \mathrm{I}$ at $65^{\circ} \mathrm{C}$ for $18 \mathrm{~h}$ using 5 units of enzyme (Sangon
Table I. Characteristics of the study population.

\begin{tabular}{lccc}
\hline Group & Male, $\mathrm{n}$ & Female, $\mathrm{n}$ & Age (years, mean \pm SD) \\
\hline PC & 52 & 39 & $47.1 \pm 9.1$ \\
Control & 45 & 35 & $47.5 \pm 7.4$ \\
\hline
\end{tabular}

PC, pancreatic cancer. Age, $\mathrm{P}=0.718$; Gender, $\mathrm{P}=0.906$.

Table II. Genotype distribution in the Hardy-Weinberg equilibrium.

\begin{tabular}{ccccc}
\hline Genotype & $\begin{array}{c}\text { Predictive } \\
\text { value (\%) }\end{array}$ & $\begin{array}{c}\text { Observed } \\
\text { value (\%) }\end{array}$ & $\chi^{2}$ & P-value \\
\hline FokI & & & 2.015 & 0.156 \\
CC & 43.1 & 46.3 & & \\
CT & 45.1 & 38.7 & & \\
TT & 11.8 & 15.0 & & \\
BsmI & & & 0.266 & 0.606 \\
CC & 33.8 & 32.5 & & \\
CT & 48.7 & 51.2 & & \\
TT & 17.5 & 16.3 & & \\
\hline
\end{tabular}

Biotech, Inc.) for each $20 \mu \mathrm{l}$ reaction. After digestion, the PCR products were separated using $2 \%$ agarose gel containing ethidium bromide and visualized under short-wave UV light. Fragments of 650 and 150 bp were visible after the 800-bp product was digested by the $B s m I$ restriction enzyme. DNA from homozygotic individuals lacking a $B s m \mathrm{I}$ restriction site (BB) appeared on the gel as a single 800-bp band. All the primers were synthesized by Sangon Biotech, Inc.

Statistical analysis. Statistical analysis was performed using SPSS 13.0 statistical software (SPSS Inc., Chicago, IL, USA) and data are presented as mean \pm SD. Comparisons between two groups were performed using independent t-tests. The $\chi^{2}$ analysis was applied to determine the difference in the genotype and gene frequency. Odds ratios (ORs) and $95 \%$ confidence intervals (95\% CIs) were calculated from unconditional logistic regression models. $\mathrm{P}<0.05$ was considered to indicate a statistically significant difference.

\section{Results}

Patient characteristics. In our study, 91 PC patients (52 males and 39 females) were diagnosed histopathologically following surgery or endoscopic ultrasonography fine-needle aspiration (EUS-FNA) and the mean age of patients was $47.1 \pm 9.1$ years. We recruited 80 healthy volunteers (controls; 45 males and 35 females) and their mean age was $47.5 \pm 7.4$ years (Table I). Initially, Pearson's $\chi^{2}$ test was performed to examine the genotypic distribution of the control population. VDR FokI and BsmI genotypic distributions were calculated according to the Hardy-Weinberg equilibrium, with P-values of 0.156 and 0.606 , respectively (Table II). The PC patients and control 
Table III. Association of VDR FokI and BsmI polymorphisms and PC risk.

\begin{tabular}{|c|c|c|c|c|c|}
\hline \multirow[b]{2}{*}{ Genotype } & \multicolumn{2}{|c|}{ Group } & \multirow[b]{2}{*}{ OR } & \multirow[b]{2}{*}{$95 \% \mathrm{CI}$} & \multirow[b]{2}{*}{ P-value } \\
\hline & $\mathrm{PC}, \mathrm{n}(\%)$ & Control, n (\%) & & & \\
\hline \multicolumn{6}{|l|}{ Fok $\mathrm{I}^{\mathrm{a}}$} \\
\hline $\mathrm{FF}(\mathrm{CC})$ & $22(24.2)$ & $37(46.3)$ & 1 & & \\
\hline $\mathrm{Ff}(\mathrm{CT})$ & $46(50.5)$ & 31 (38.7) & 2.496 & $1.243-5.011$ & 0.009 \\
\hline $\mathrm{ff}(\mathrm{TT})$ & $23(25.3)$ & $12(15.0)$ & 3.223 & $1.344-7.733$ & 0.008 \\
\hline $\mathrm{Ff}+\mathrm{ff}$ & 69 & 43 & 2.699 & $1.408-5.173$ & 0.002 \\
\hline $\mathrm{FF}$ & 22 & 37 & & & \\
\hline $\mathrm{FF}+\mathrm{Ff}$ & 68 & 43 & & & \\
\hline $\mathrm{F}$ & $90(49.5)$ & $105(65.6)$ & 1 & & \\
\hline $\mathrm{f}$ & $92(50.5)$ & $55(34.4)$ & 1.952 & $1.261-3.021$ & 0.003 \\
\hline \multicolumn{6}{|l|}{$B s m I^{\mathrm{b}}$} \\
\hline $\mathrm{BB}(\mathrm{AA})$ & $23(25.3)$ & $26(32.5)$ & 1 & & \\
\hline $\mathrm{Bb}(\mathrm{AG})$ & $40(44.0)$ & $41(51.2)$ & 1.103 & $0.542-2.244$ & 0.787 \\
\hline bb (GG) & $28(30.7)$ & $13(16.3)$ & 2.435 & $1.026-5.780$ & 0.042 \\
\hline $\mathrm{Bb}+\mathrm{bb}$ & 68 & 54 & 1.424 & $0.732-2.768$ & 0.297 \\
\hline $\mathrm{BB}$ & 23 & 26 & & & \\
\hline $\mathrm{Bb}+\mathrm{bb}$ & 68 & 54 & & & \\
\hline B & $86(47.3)$ & $93(58.1)$ & 1 & & \\
\hline $\mathrm{b}$ & $96(52.7)$ & $67(41.9)$ & 0.645 & $0.421-0.990$ & 0.045 \\
\hline
\end{tabular}

VDR, vitamin D receptor; PC, pancreatic cancer; OR, odds ratio; CI, confidence interval. ${ }^{\mathrm{a} P \text { trend }}=0.009$; ${ }^{\text {brend }}=0.0082$.

Table IV. Combined analysis of VDR FokI and BsmI genotypes between PC patients and controls.

\begin{tabular}{|c|c|c|c|c|c|}
\hline \multirow[b]{2}{*}{ Genotype } & \multicolumn{2}{|c|}{ Group } & \multirow[b]{2}{*}{ OR } & \multirow[b]{2}{*}{$95 \% \mathrm{CI}$} & \multirow[b]{2}{*}{ P-value } \\
\hline & $\begin{array}{c}\text { PC, n (\%) } \\
\text { Total n=91 }\end{array}$ & $\begin{array}{c}\text { Control, } \mathrm{n}(\%) \\
\text { Total } \mathrm{n}=80\end{array}$ & & & \\
\hline FFBB & $6(6.59)$ & $14(17.50)$ & 1 & & \\
\hline $\mathrm{FFBb}$ & $9(9.89)$ & $16(20.00)$ & 1.313 & $0.373-4.616$ & 0.671 \\
\hline FFbb & $7(7.69)$ & $7(8.75)$ & 2.333 & $0.565-9.639$ & 0.296 \\
\hline FfBB & $10(10.99)$ & $8(10.00)$ & 2.917 & $0.768-11.070$ & 0.188 \\
\hline $\mathrm{FfBb}$ & $25(27.47)$ & $19(23.75)$ & 3.07 & $0.995-9.477$ & 0.062 \\
\hline Ffbb & 11 (12.09) & $4(5.00)$ & 6.417 & $1.444-28.511$ & 0.018 \\
\hline ffBB & $7(7.69)$ & $4(5.00)$ & 4.083 & 0.861-19.371 & 0.128 \\
\hline $\mathrm{ffBb}$ & $6(6.59)$ & $6(7.50)$ & 2.333 & $0.53-10.267$ & 0.288 \\
\hline ffbb & 10 (10.99) & $2(2.50)$ & 11.667 & $1.940-70.178$ & 0.009 \\
\hline
\end{tabular}

VDR, vitamin D receptor; PC, pancreatic cancer; OR, odds ratio; CI, confidence interval.

population were age- and gender-matched using Chi-square analysis, revealing P-values of 0.718 and 0.906 , respectively, as shown in Table I.

VDR FokI polymorphism. As shown in Table III, the number of PC patients with genotype FF was 22 (24.2\%), Ff was $46(50.5 \%)$ and ff was $23(25.3 \%)$. For the control population, there were $37(46.3 \%), 31(38.7 \%)$ and $12(15.0 \%)$ cases with FF, Ff and ff, respectively. Thus, the difference in the occur- rence of the FF genotype between the PC patients and control population was significant $\left(\mathrm{P}^{\text {trend }}=0.009\right)$. The percentage of PC patients with genotypes FF or combined Ff/ff was $24.2 \%$ and $75.8 \%$ and for the control population was $46.3 \%$ and $53.7 \%$, respectively. This difference was statistically significant $(\mathrm{P}=0.002 ; \mathrm{OR}=2.699 ; 95 \% \mathrm{CI}, 1.408-5.173)$. There was a significant difference between genotypes $\mathrm{FF}$ and $\mathrm{Ff}(\mathrm{P}=0.009$; $\mathrm{OR}=2.496 ; 95 \% \mathrm{CI}, 1.243-5.011)$ and genotypes $\mathrm{FF}$ and $\mathrm{ff}$ $(\mathrm{P}=0.008, \mathrm{OR}=3.223,95 \% \mathrm{CI}, 1.344-7.733)$. The incidence 
of $\mathrm{F}$ and $\mathrm{f}$ alleles for the FokI polymorphism was $90(49.4 \%)$ and $92(50.6 \%)$ cases in the PC patients and 105 (65.6\%) and $55(34.4 \%)$ cases in the control population, respectively. The difference in the allele frequency between the two groups was statistically significant ( $\mathrm{F}$ vs. f allele; $\mathrm{P}=0.035 ; \mathrm{OR}=1.952$; 95\% CI, 1.261-3.021).

VDR BsmI polymorphism. As shown in Table III, the frequencies of the $\mathrm{BB}, \mathrm{Bb}$ and bb genotypes in PC patients were $23(25.3 \%), 40(44.0 \%)$ and $28(30.7 \%)$ and in the control population were $26(32.5 \%), 41(51.2 \%)$ and 13 (16.3\%), respectively. There was not a significant difference in BB frequency between the PC and control populations $\left(P^{\text {trend }}=0.082\right)$. The genotype frequency percentage of BB and combined $\mathrm{Bb} / \mathrm{bb}$ was not significantly different $(\mathrm{P}=0.297$; $\mathrm{OR}=1.424 ; 95 \% \mathrm{CI}, 0.732-2.768)$ between the PC patients (25.3 and $74.7 \%$, respectively) and control population (32.5 and $67.5 \%$, respectively); however, there was a significant difference between genotypes $\mathrm{BB}$ and $\mathrm{bb}(\mathrm{P}=0.042 ; \mathrm{OR}=2.435$; 95\% CI, 1.026-5.780). The frequency of $B$ and $b$ alleles for the BsmI polymorphism were $86(47.3 \%)$ and $96(52.7 \%)$ in PC patients and $93(58.1 \%)$ and 67 (41.9\%) in the control population, respectively. The difference between the two groups was statistically significant (B vs. b allele; $\mathrm{P}=0.045 ; \mathrm{OR}=0.645$; 95\% CI, 0.421-0.990).

Combined analysis of genotypes FokI and BsmI. We pooled the data for FokI and BsmI genotypes of the VDR gene for PC patients and the control population to analyze the cumulative effect of FokI and BsmI polymorphisms, as shown in Table IV. Individuals with genotype ffbb had an 11.66-fold risk of $\mathrm{PC}$ compared with those of genotype FFBB (OR=11.667; $\mathrm{P}=0.009$ ) and genotype Ffbb individuals had a 6.417-fold risk of PC compared with those of genotype FFBB $(\mathrm{OR}=6.417$; $\mathrm{P}=0.018$ ). There were no significant differences in risk of $\mathrm{PC}$ between the other genotypes, as shown in Table IV.

\section{Discussion}

PC is one of the most lethal types of human cancer, responsible for $>250,000$ mortalities and the fifth leading cause of cancerassociated deaths worldwide in 2007 (2). The majority of patients who contract the disease usually succumb to it within a few months of diagnosis, despite surgical or medical intervention. The incidence rate of PC is approximately the same as the mortality rate and the 5 -year survival rate is $<1 \%$ (14). Carcinoma of the exocrine pancreas is an increasingly common cancer, but no effective chemotherapy has been developed for patients with advanced disease (15). It has previously appeared that receptors in PC, such as estrogen receptors (ER), may be responsive to endocrine therapy. However, subsequent clinical trials with these receptors have not supported this therapy (16).

Epidemiological studies show that individuals living at higher latitudes are at an increased risk of PC and are more likely to succumb to the cancer than those living at lower latitudes (5). One reason is that $1,25(\mathrm{OH})_{2} \mathrm{VitD}$ affects $>200$ genes to regulate proliferation, differentiation, apoptosis and angiogenesis of cells (17-19). Also, in vitro studies have demonstrated that $1,25(\mathrm{OH})_{2} \mathrm{VitD}$ and its synthetic analogs are able to inhibit the proliferation of PC cell lines (20). The VDR and its gene polymorphisms may also be important (21). Genetic studies have investigated the possible association between various histotypes of cancer and the detection of specific SNPs of the VDR gene (VDR-SNPs). Polymorphisms in the VDR gene have been shown to affect VDR mRNA and protein levels (22), which in turn may affect the immunomodulatory function of VDR (23). Approximately 200 different VDR-SNPs have been described; however, the VDR polymorphisms which are most frequently associated with tumorigenesis are FokI, BsmI, TaqI, ApaI, EcoRV and Cdx2 (24-26). The most frequently studied SNPs are the RFLPs FokI and BsmI. The FokI RFLP, located in the coding region of the VDR gene, leads to the production of a VDR protein that is three amino acids longer than normal. Although no significant differences in ligand affinity, DNA binding or transactivation activity have been identified between these two VDR forms, the shorter VDR variant exhibits higher potency than the longer one. The BsmI RFLP is intronic and located at the 3 ' end of the gene. BsmI does not alter the amount, structure or function of the final VDR protein produced, but it is strongly linked with a poly(A) repeat and may affect VDR mRNA stability. Thus, VDR polymorphisms have important implications for VD signaling and are associated with various malignancies $(27,28)$. A number of studies have reported the role of the VDR gene in different malignancies, yet no studies have been carried out to evaluate the role of VDR gene polymorphisms in PC. To the best of our knowledge, this is the first study to investigate the association between VDR polymorphisms and the risk of PC.

VD is involved in the regulation of cell proliferation and differentiation in vitro and in vivo (29). The results of this study revealed that genetic heterozygous variants of FokI are associated with a decreased risk of PC in a North Chinese population, whereas the effects of $B s m I$ were not significant. The difference in the allele frequencies was statistically significant ( $\mathrm{F}$ vs. f allele, $\mathrm{P}=0.003 ; \mathrm{OR}=1.952 ; 95 \% \mathrm{CI}$, 1.261-3.021. B vs. b allele, $\mathrm{P}=0.045$; $\mathrm{OR}=0.645 ; 95 \% \mathrm{CI}$, 0.421-0.990) between PC patients and the control population. When the two genotypes, FokI and BsmI, were combined to analyze their cumulative effect in PC, we identified that ffbb and Ffbb genotypes have an increased risk of PC. This may be attributed to the haplotypic effect associated with the linkage disequilibrium of these two polymorphic sites. Thus, we propose that the FokI and BsmI polymorphisms of VDR are potential prognostic variables which may predict the risk of developing PC in the North Chinese population.

A number of potential improvements may be considered for any further studies. Firstly, more PC and control samples are required to effectively test the effects of variables. Secondly, further investigation of VDR-SNPs, including TaqI and ApaI, to analyze the association between SNPs and PC and various clinicopathological parameters for PC patients and healthy volunteers is required. Comparison of the various risk factors for PC (age, smoking, diabetes and chronic hepatitis B infection) and the frequency of VDR genotypes in PC patients may also be considered for further investigation.

In conclusion, data from this study showed that the FokI and $B s m \mathrm{I}$ polymorphisms were associated with a higher risk of PC among the North Chinese population. Furthermore, this study showed for the first time that these two polymorphisms in the VDR gene are potential determinants in PC 
patients. The main aim of this study was to understand the role of VDR gene polymorphisms in the etiology of PC in China. Additional studies on a larger population size are warranted to elucidate the role of genetic variations of VDR and $\mathrm{PC}$ risk.

\section{References}

1. Jemal A, Siegel R, Ward E, et al: Cancer statistics, 2006. CA Cancer J Clin 56: 106-130, 2006.

2. Cancer Research UK: UK Pancreatic Cancer Statistics. http:// info.cancerresearchuk.org/cancerstats/types/pancreas. Accessed October 24, 2006.

3. Le Scodan R, Mornex F, Girard N, et al: Preoperative chemoradiation in potentially resectable pancreatic adenocarcinoma: feasibility, treatment effect evaluation and prognostic factors, analysis of the SFRO-FFCD 9704 trial and literature review. Ann Oncol 20: 1387-1396, 2009.

4. Holick MF: Vitamin D deficiency. N Engl J Med 357: 266-281, 2007.

5. Nagpal S, Na S and Rathnachalam R: Noncalcemic actions of vitamin D receptor ligands. Endocr Rev 26: 662-687, 2005.

6. Muszkat P, Camargo MB, Griz LH and Lazaretti-Castro M: Evidence-based non-skeletal actions of vitamin D. Arq Bras Endocrinol Metabol 54: 110-117, 2010.

7. Florentin M, Elisaf MS, Mikhailidis DP and Liberopoulos EN: Vitamin D and metabolic syndrome: is there a link? Curr Pharm Des 16: 3417-3434, 2010.

8. Giovannucci E, Liu Y, Rimm EB, Hollis BW, Fuchs CS, Stampfer MJ and Willett WC: Prospective study of predictors of vitamin D status and cancer incidence and mortality in men. J Natl Cancer Inst 98: 451-459, 2006.

9. Mahmoudi T, Mohebbi SR, Pourhoseingholi MA, et al: Vitamin $D$ receptor gene ApaI polymorphism is associated with susceptibility to colorectal cancer. Dig Dis Sci 55: 2008-2013, 2010.

10. Kizildag S, Gulsu E, Bagci O, Yuksel E and Canda T: Vitamin $\mathrm{D}$ receptor gene polymorphisms and male breast cancer risk in Turkish population. J BUON 16: 640-645, 2011.

11. Arjumand W, Ahmad ST, Seth A, et al: Vitamin D receptor FokI and BsmI gene polymorphism and its association with grade and stage of renal cell carcinoma in North Indian population. Tumor Biol 33: 23-31, 2012

12. Shui IM, Mucci LA, Kraft P, Tamimi RM, Lindstrom S, et al: Vitamin D-related genetic variation, plasma vitamin $\mathrm{D}$, and risk of lethal prostate cancer: a prospective nested case-control study. J Natl Cancer Inst 104: 690-699, 2012.

13. Harries LW, Stubbins MJ, Forman D, Howard GC and Wolf CR: Identification of genetic polymorphisms at the glutathione S-transferase Pi locus and association with susceptibility to bladder, testicular and prostate cancer. Carcinogenesis 18: 641-644, 1997.
14. Ries LAG, Eisner MP, Kosary CL, et al; National Cancer Institute: SEER cancer statistics review, 1975-2002. http://seer. cancer.gov/csr/1975_2002/. Accessed September 19, 2007.

15. Vogt DP: Pancreatic cancer: a current overview. Curr Surg 57: 214-220, 2000.

16. Wong A and Chan A: Survival benefit of tamoxifen therapy in adenocarcinoma of pancreas. Cancer 71: 2200-2203, 1993.

17. Mantell DJ, Owens PE, Bundred NJ, Mawer EB and Canfield AE $1 \alpha, 25$-dihydroxyvitamin $\mathrm{D}(3)$ inhibits angiogenesis in vitro and in vivo. Circ Res 87: 214-220, 2000.

18. Zeeb $\mathrm{H}$ and Greinert $\mathrm{R}$ : The role of vitamin $\mathrm{D}$ in cancer prevention: does UV protection conflict with the need to raise low levels of vitamin D? Dtsch Arztebl Int 107: 638-643, 2010.

19. International Agency for Research on Cancer; IARC Working Group Reports: Vitamin D and Cancer, 2008. http://www.iarc. fr/en/publications/pdfs-online/wrk/wrk5/index.php. Accessed November 24, 2008

20. Colston KW, James SY, Ofori-Kuragu EA, Binderup L and Grant AG: Vitamin D receptors and anti-proliferative effects of vitamin D derivatives in human pancreatic carcinoma cells in vivo and in vitro. Br J Cancer 76: 1017-1020, 1997.

21. Albrechtsson E, Jonsson T, Möller S, Höglund M, et al: Vitamin D receptor is expressed in pancreatic cancer cells and a vitamin D3 analogue decreases cell number. Pancreatology 3: 41-46, 2003.

22. Ogunkolade BW, Boucher BJ, Prahl JM, Bustin SA, Burrin JM Noonan K, et al: Vitamin D receptor (VDR) mRNA and VDR protein levels in relation to vitamin D status, insulin secretory capacity, and VDR genotype in Bangladeshi Asians. Diabetes 51: 2294-2300, 2002.

23. Cross HS: Extrarenal vitamin D hydroxylase expression and activity in normal and malignant cells: modification of expression by epigenetic mechanisms and dietary substances. Nutr Rev 65 : S108-S112, 2007.

24. Chen TC and Kittaka A: Novel vitamin d analogs for prostate cancer therapy. ISRN Urol 2011: 301490, 2011.

25. Köstner K, Denzer N, Müller CS, Klein R, Tilgen W and Reichrath J: The relevance of vitamin D receptor (VDR) gene polymorphisms for cancer: a review of the literature. Anticancer Res 29: 3511-3536, 2009.

26. Raimondi S, Johansson H, Maisonneuve P and Gandini S: Review and meta-analysis on vitamin D receptor polymorphisms and cancer risk. Carcinogenesis 30: 1170-1180, 2009.

27. Jurutka PW, Whitfield GK, Hsieh JC, Thompson PD, Haussler CA and Haussler MR: Molecular nature of the vitamin D receptor and its role in regulation of gene expression. Rev Endocr Metab Disord 2: 203-216, 2001.

28. Uitterlinden AG, Fang Y, Van Meurs JB, Pols HA and Van Leeuwen JP: Genetics and biology of vitamin D receptor polymorphisms. Gene 338: 143-156, 2004.

29. Makariou S, Liberopoulos EN, Elisaf M and Challa A: Novel roles of vitamin D in disease: what is new in 2011? Eur J Intern Med 22: 355-362, 2011. 